\title{
Measuring the Impact of Asset Complementarities: The Case of Rural Peru*
}

\author{
JAVIER ESCOBAL** \\ GRADE, Perú \\ MÁXIMO TORERO** \\ IFPRI, Washington D.C.
}

The exact type, critical mass, and combination of public and private assets needed to move out of poverty have not been sufficiently studied. This paper analyzes three types of public infrastructure and services: a) "traditional infrastructure" such as transportation, sewer systems, water, electricity which do not generate positive network externalities; $b$ ) «human-capital-generating public services» that are capable of creating mobile private assets, such as schooling and health services and c) «information and communication technologies», such as telephone or Internet, all of which generate network externalities. Using Peruvian LSMS data we quantify the differential impact on poverty of each of these types of investments, as well as the interaction effect between so-called traditional types of infrastructure and those which generate network externalities.

JEL: H40 I30 R13 R53

Keywords: Development, Poverty Trap, Public Assets, Complementarity, Infrastructure

\section{INTRODUCTION}

Several authors have suggested that one of the fundamental causes of poverty, lack of economic growth and income inequality is an unequal access and

\footnotetext{
* This paper summarizes one of the research outcomes supported by the funds provided by the Global Development Network (GDN) under the Global Development Network Awards in the Outstanding Research on Development 2000 and also during the time Maximo Torero was under the von Humboldt Foundation Fellowship. We are grateful to J. de la Roca, C. Ponce, G. Gajate and C. Mendieta for excellent research assistance in this project. All errors remaining are ours.

***E-mails: jescobal@grade.org.pe,m.torero@cgiar.org
} 
possession of assets. In this respect changes in the distribution of key assets underlie long-term changes in income distribution and growth. ${ }^{1}$

The dispersion of spending or income, as well as the probability of individuals and families of being poor or non-poor, depends on their stock of assets and the rate of return in the usage of those assets. If we assume, aside from possible interactions between assets, that the marginal rate of return of any physical, human, financial, public or organizational capital does not depend on asset base, the distribution of assets plays the most critical role in the determination of the distribution of income and spending.

Despite the fact that access to public and private assets continues to be restricted and unevenly distributed in rural Peru, changes in the level and in the pattern of ownership of these assets during the last 15 years have been quite dramatic. For example, in 1985 the level of schooling of heads of household was very low and unequal in the rural sector. In 1997, average years of education had increased from 2.9 to 5 , and inequality has declined: the schooling years among the poorest sectors has almost doubled while among the richest it has increased about $50 \%$. The average family size in the poorest quintile was $50 \%$ higher than the average in the richest quintile. On the other hand, access to credit was relatively segmented, being very low in the poorest quintile. The 1997 Peruvian LSMS survey revealed that although global access to credit had fallen from $23 \%$ of farmers to $16 \%$, it had increased for the poorest quintile and fallen for the other quintiles, particularly the richest. In the case of access to basic services infrastructure (electricity, telephone services and water and sewerage), levels of access were low and highly inequitable in 1985. In contrast in 1997, at least in the case of water and electricity, access had doubled: $27 \%$ and $24 \%$ of households had access to these services, respectively. However dispersion in access by spending decile turned now to be much more pronounced than 15 years ago. This is so because the pattern of invest in public infrastructure had been biased against the poorest segments in rural Peru leaving them in a poverty trap.

Putting these changes in asset ownership in perspective, the purpose of this paper is to evaluate, using household and communal level surveys, the differential impact on poverty of different types of asset investments. We consider three types of public goods and services: a) "traditional infrastructure" such as transportation, sewer systems, water, electricity which do not generate positive network externalities; b) "human-capital-generating public services" that are capable of creating mobile private assets, such as schooling and health services and c) "information and communication technologies", such as telephone or Internet, all of which generate network externalities.

We also look at the interaction effects on poverty between the so-called traditional infrastructure and those that generate network externalities. In addition, given the indivisible and irreversible nature of most of these investments, we intend to evaluate the critical mass of investments of each type required to create

\footnotetext{
${ }^{1}$ See for example Birdsall and Londoño (1998) or Bebbington(1999).
} 
the externalities and positive spillovers over private assets for effective poverty reduction strategies.

The paper is divided in 5 sections including this introduction. In section two a brief overview of poverty and income inequality trends in Peru is presented as well as an initial assessment of the relationship between asset inequality and poverty outcomes. In section three we analyze the importance of geographic constraints that characterize rural Peru, showing how important are these constraints as irreversible initial conditions explaining a possible poverty trap. We analyze to what extent these initial adverse conditions can be explained when one takes into account the spatial concentration of households with readily observable non-geographic characteristics, in particular public and private assets. This does not mean, however that geography is not important but that its influence on expenditure level and growth differential comes about through a spatially uneven provision of public infrastructure.

In section four we concentrate our analysis in evaluating, using household and communal level surveys, the differential impact on poverty of each of the types of assets mentioned above (human capital, traditional infrastructure and information and communication technologies), as well as the way they interact. In addition, we carry out a initial set of simulations as a first evaluation of the importance of a critical mass of investments of each type required to create the externalities and positive spillovers over private assets for effective poverty reduction strategies. Finally, section five summarizes our findings.

\section{Poverty and Asset Inequality in Peru}

Poverty in Peru has changed dramatically over the last three decades (see Table 1), experiencing not only an important reduction but also compositional changes. While in the early 1970s poverty was largely rural - two-thirds of the poor were rural dwellers employed in agriculture - the picture reversed in the mid1990s, at which point two-thirds of the poor were reported to be urban dwellers. Hence, while urban poverty rates have risen ten points over the last 28 years, in the rural sector poverty has fallen 18 points. In this sense, it is possible that the entire long-term reduction in poverty could be a rural phenomenon arising out of a major migratory process. ${ }^{2}$

\footnotetext{
${ }^{2}$ The 1991 survey does not include tropical forest areas and the rural coast, while the other surveys are representative at the national level.
} 
TABLE 1

POVERTY INDICATORS BY REGION: 1971, 1985, 1991, 1994 AND 1996

(By family spending - percentages)

\begin{tabular}{lcccccc}
\hline Region & $1971-72$ & 1985 & 1991 & 1994 & 1997 & 2000 \\
\hline Peru & 64.0 & 43.1 & 59.0 & 53.4 & 50.7 & 54.1 \\
Urban & 39.6 & 36.0 & 53.3 & 50.4 & 48.9 & 49.8 \\
Rural & 84.5 & 55.2 & 80.7 & 65.5 & 64.8 & 66.1 \\
\hline
\end{tabular}

Authors' own figures based on ENCA (1971-72) and ENNIV 1985-86, 1991, 1994, 1997 and 2000.

Although Peru continues to be a country with high poverty rates and, by international standards highly unequal income distribution, when we look at the long term trends in income distribution the Gini figures show a downward trend. Since the 1970 s a clear pattern of reduction in dispersion has been observed. As shown in Graph 1 the Gini coefficient of family income fell from 0.55 to 0.40 between the early 1970s and the 1990s. The percentage of total income received by the poorest half of the population rose from $10.7 \%$ to $24.5 \%$ in 1996 , while the share of richest half fell from $61 \%$ to $43 \%$. This trend in income distribution from the $1970 \mathrm{~s}$ can also be corroborated by the estimate of indicators of concentration based on family spending. ${ }^{3}$

The connection between asset endowments and poverty alleviation is well understood in the economic literature. For example, Birdsall and Londoño (1998) suggest that one of the fundamental causes of poverty and income inequality is unequal access to and possession of assets. In this respect, it should be possible to find changes in the distribution of key assets that underlie these long-term changes in income distribution.

The dispersion of spending or income, as well as the probabilities of individuals and families being poor or non-poor, depends on their asset ownership and their rate of return which, in turn, are critically determined by the ownership or access to key complementary assets. Table 2 shows the average level of possession or access to different key assets in Peruvian urban and rural sectors. Obviously assets are not totally exogenous variables. The possession of assets depends on the possession of other assets, on changes in acquisition prices and in the expected return on the assets. However, compared to previous years (see Escobal et al. 1998), patterns of possession and access to assets by position on the scale of spending were relatively similar, although the average in some cases had changed. For example, access to electricity has increased substantially, with the exception of the poorest quintile. Access to telephones, average level of education, average years' experience and the age of the head of household also rose, although the distribution did not varied substantially.

\footnotetext{
${ }^{3}$ These results are shown in Escobal, Saavedra and Torero (1998).
} 
GRAPH 1

INCOME DISTRIBUTION IN PERU

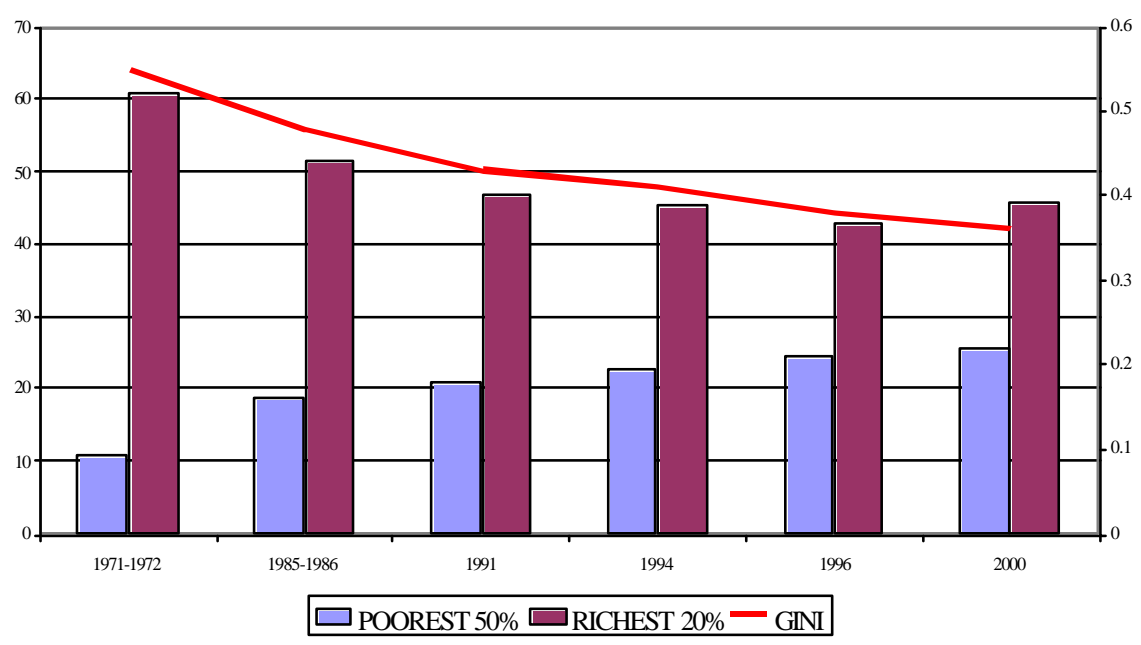

To capture the level and the changes in the disparities in the ownership of assets, Gini coefficients were calculated for some of the assets for urban and rural areas (see Graph 2). The assets with the highest degree of dispersion in urban areas are possession of durable goods and the labor experience of the head of household. The education variables reveal relatively low dispersion, a fact that is consistent with rapid expansion of the educational system, which began in the 1970s. On the other hand when we look to the rural areas the highest inequality can be found on value of land (basically due to differences in quality), on the value of durable goods and on the proportion of members with migration experience. In rural areas education inequality has also been reduced substantially as a consequence of the expansion of the educational system. It is important to note that if these calculations were done at national level, the inequality of many of these assets would be much greater because of the large gap in access to education and in infrastructure between urban and rural areas. 
TABLE 2

\begin{tabular}{|c|c|c|c|c|c|c|c|c|c|c|c|c|}
\hline & \multirow{3}{*}{ Average } & \multicolumn{4}{|c|}{ Urban Peru } & \multicolumn{7}{|c|}{ Rural Peru } \\
\hline & & & & Quintiles & & & Average & & & Quintiles & & \\
\hline & & I & II & III & IV & $\mathrm{V}$ & & I & II & III & IV & $\mathrm{V}$ \\
\hline \multicolumn{13}{|l|}{ Human capital assets } \\
\hline Average education attained by family & 9.42 & 7.72 & 8.90 & 9.87 & 10.28 & 10.33 & 5.97 & 5.09 & 5.65 & 6.15 & 6.07 & 6.91 \\
\hline Average education of the household head & 9.36 & 7.29 & 8.38 & 9.26 & 10.29 & 11.60 & 60.7 & 5.11 & 5.64 & 6.16 & 6.35 & 7.08 \\
\hline Access to primary school & N.A. & N.A. & N.A. & N.A. & N.A & N.A & 0.81 & 0.85 & 0.83 & 0.79 & 0.81 & 0.78 \\
\hline Access to secondary school & N.A. & N.A. & N.A. & N.A. & N.A & N.A & 0.24 & 0.25 & 0.22 & 0.23 & 0.30 & 0.21 \\
\hline Communal association & N.A. & N.A. & N.A. & N.A. & N.A & N.A & 0.70 & 0.74 & 0.72 & 0.74 & 0.72 & 0.59 \\
\hline Access to health services & N.A. & N.A. & N.A. & N.A. & N.A & N.A & 0.29 & 0.29 & 0.26 & 0.28 & 0.36 & 0.27 \\
\hline \multicolumn{13}{|l|}{ Traditional infrastructure } \\
\hline Drinkable water & 0.89 & 0.79 & 0.85 & 0.91 & 0.92 & 0.96 & 0.35 & 0.20 & 0.33 & 0.37 & 0.40 & 0.46 \\
\hline Sewerage & 0.84 & 0.67 & 0.79 & 0.86 & 0.91 & 0.97 & 0.10 & 0.08 & 0.08 & 0.11 & 0.07 & 0.18 \\
\hline Electricity & 0.95 & 0.84 & 0.96 & 0.98 & 0.98 & 0.98 & 0.34 & 0.24 & 0.24 & 0.32 & 0.40 & 0.51 \\
\hline Distance to roads* & 5.83 & 7.60 & 3.69 & 7.23 & 8.98 & 1.64 & 2.45 & 3.29 & 2.75 & 2.57 & 2.10 & 1.54 \\
\hline \multicolumn{13}{|l|}{ Information and communication technologies } \\
\hline Telephone & 0.36 & 0.07 & 0.18 & 0.34 & 0.49 & 0.74 & 0.01 & 0.00 & 0.00 & 0.00 & 0.00 & 0.03 \\
\hline Access to public phones & 0.91 & 0.89 & 0.89 & 0.91 & 0.93 & 0.94 & 0.15 & 0.12 & 0.11 & 0.14 & 0.15 & 0.23 \\
\hline
\end{tabular}

*For Urban Peru de distance is to the nerest market. 

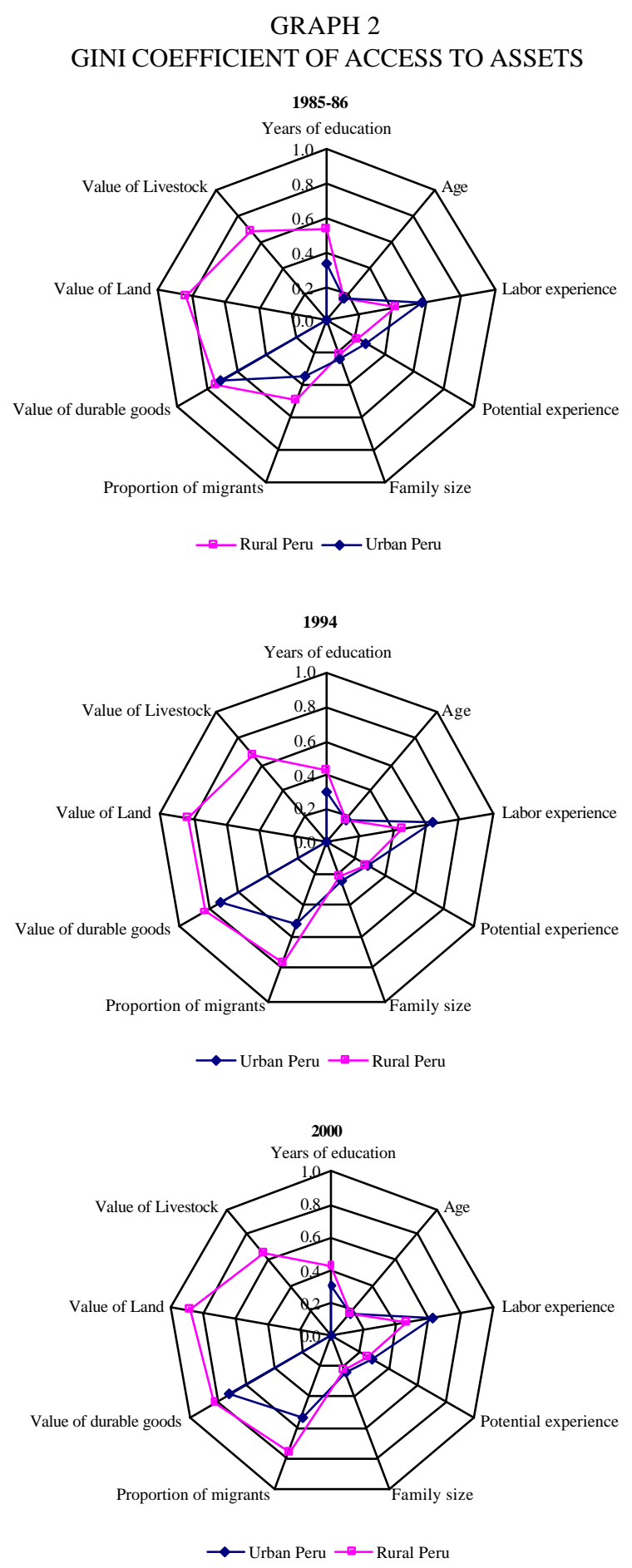


\section{Geographic Restrictions}

Current literature had argued (Jalan and Ravallion,1998; Engerman and Sokoloff, 1998) that geography has a causal role in determining how household welfare evolves over time. By this view, geographic externalities arising from natural geographic characteristics could be the main reason explaining why poor households cannot escape out of poverty. Instead, our hypothesis is that what seem to be sizable geographic differences in living standards in Peru can be almost fully explained when one takes into account the spatial concentration of households with readily observable non-geographic characteristics, in particular public and private assets. In other words, the same observationally equivalent household has a similar expenditure level in one place as in another with different geographic characteristics such as altitude or temperature. This does not mean however that geography is not important, but that its influence on expenditure level and growth differential comes about through a spatially uneven provision of public infrastructure. If this is so, then it is important for policy to understand the importance of an adequate provision of public and private assets.

Specifically in the case of Peru, the geography question is of great importance. The Peruvian astonishing variety of ecological areas, including 84 different climate zones and landscapes with rainforests, high mountain ranges and dry deserts, could play a large role in explaining regional variations in income and welfare. Therefore, we are interested in testing if geography plays or not a causal role in determining the evolution of household welfare over time (Escobal and Torero, 2000).

Following Escobal and Torero (2000) and Ravallion and Wodon (1997) we break down the geographic effects into their component elements, taking into account observed differences in asset endowments and rate of return of asset ownership across regions. For this purpose, we compute the expected gain (or loss) in consumption from living in one geographic region (coast for example) against living in another adverse geographic region (i.e. mountains) specifying how much of the gain is explained by geographical variables and location (urban or rural areas) and how much by the presence of all the types of infrastructure and private assets:

$$
\left(\bar{X}_{M}-\bar{X}_{C}\right) \hat{\beta}
$$

where $\bar{X}_{M, C}$ are the sample means for mountain and coast regions for example, and $\hat{\beta}$ is the parameter of the respective variables under analysis (i.e. geographical, location, infrastructure and private assets). ${ }^{4}$ This break-down represents the differential impact on a household's standard of all non-excluded variables in the two regions.

${ }^{4}$ The parameter can be obtained estimating expenditure as a function of geographic characteristics, private assets, and the different types of public assets. 
For this break-down we have assumed that parameters are stable within the three main geographic regions: coast, highland and jungle. This initial break-down is shown in Table 3. In the first column we see that most of the difference in log per capita expenditure between the highland and the coast can be accounted for by the differences in infrastructure endowments and private assets. In other words, once the main geographic variables are accounted for (altitude, temperature and surface characteristics), only private assets and infrastructure endowments are needed to explain regional expenditure differences. Similarly, the second column shows the break-down of the differences in log per capita expenditure between the jungle area and the coast, showing again that once main geographic variables are accounted for most of the regional expenditure differences can be explained by infrastructure endowment and private asset composition.

Obviously, the fact that geography has no additional impact on regional per-capita expenditure differences has to do with the fact that key infrastructure variables such as school and medical facilities, access to electricity, water and sanitation, as well as private assets, have dampened the effect of geography on regional expenditure differentials. To see this, Table 4 performs the same breakdown exercise introducing each set of variables sequentially. First geography variables are entered in the model alone and the break-down exercise is conducted only with these variables. In this case, geography is highly significant in explaining per-capita expenditure differentials between the highland and coastal areas, as well as between the jungle and coastal areas of Peru. Geography remains highly significant even after we introduce location variables and their cross-products into the analysis. However, once infrastructure variables come into play in the analysis, the impact of geography disappears, as the coefficients associated with these types of variables are shown to be jointly non-significant. This could be because, in the models without infrastructure, the geography variables were choosing their effect and therefore when improving our specification the effect of these variables disappears.

These results suggest that a poverty trap linked to adverse geographic conditions may be overcome with an adequate provision of private and public assets. However, the exact type, critical mass, and combination of public and private assets needed to overcome these poverty traps remain largely unstudied in Peru, along with presenting a knowledge gap in the international literature on poverty. To try to contribute towards filling that gap, in the next section we evaluate, using household- and community- level surveys, the differential impact on poverty of each of these types of investments, as well as the interaction effect between the so-called traditional forms of infrastructure and those that generate network externalities. 
TABLE 3

DECOMPOSITION OF REGIONAL PER CAPITA EXPENDITURE DIFFERENCES (Log differences)

\begin{tabular}{|c|c|c|c|c|}
\hline Group of variables & Highland-coas & & Jungle-coa: & \\
\hline Geography & -0.163 & & 0.031 & \\
\hline Altitude & -0.036 & & -0.004 & \\
\hline Temperature & -0.235 & $*$ & 0.173 & $*$ \\
\hline Temperature squared & 0.117 & & -0.121 & \\
\hline Igneous rocks & 0.015 & $* *$ & -0.004 & $* *$ \\
\hline Sediments rocks & -0.004 & & $-0-009$ & \\
\hline Land depth & -0.022 & & -0.005 & \\
\hline Location & 0.050 & & 0.039 & \\
\hline Urbanization & 0.055 & & 0.038 & \\
\hline Distance to province capital & -0.005 & & 0.001 & \\
\hline Geography $*$ location & 0.081 & $* *$ & 0.007 & $* *$ \\
\hline Urbanization*altitude & 0.081 & $* *$ & 0.007 & $* *$ \\
\hline Infrastructure & -0.024 & $* *$ & -0.064 & $* *$ \\
\hline Perinhabitant schools in town & 0.024 & & 0.023 & \\
\hline Perinhabitant medical centers in town & 0.010 & & 0.009 & \\
\hline Basic needs & -0.058 & * & -0.095 & $*$ \\
\hline Private assets & -0.185 & * & -0.258 & $*$ \\
\hline Household size & -0.031 & $*$ & -0.064 & $*$ \\
\hline Schooling years (household head) & -0.061 & $*$ & -0.065 & $*$ \\
\hline Schooling years (other members) & -0.069 & * & -0.012 & $*$ \\
\hline Potential labor experience & -0.013 & * & -0.024 & $*$ \\
\hline Household head gender & 0.000 & & -0.001 & \\
\hline Number of migrantes & -0.009 & $* *$ & -0.005 & $* *$ \\
\hline Spell of illness (household head) & 0.000 & & 0.000 & \\
\hline Savings & 0.002 & $*$ & 0.000 & $*$ \\
\hline Value of durable goods & -0.003 & & 0.004 & \\
\hline Explained & -0.241 & & -0.244 & \\
\hline Residual & 0.024 & & 0.077 & \\
\hline Total & -0.217 & & -0.167 & \\
\hline
\end{tabular}

Note: Parameters are significant at the $*=0.01$ level and $* *$ at the 0.5 level.

Source: Author's calculation based on 1994 LSMS. 
TABLE 4

DECOMPOSITION OF REGIONAL PER CAPITA EXPENDITURE DIFFERENCES, BY MODEL

\begin{tabular}{|c|c|c|c|c|c|c|c|c|c|c|c|}
\hline \multirow[b]{2}{*}{ Group of variables } & \multicolumn{5}{|c|}{ Highland-coast } & \multicolumn{6}{|c|}{ Jungle-coast } \\
\hline & 1 & $1+2$ & $1+2+3$ & $1+2+3+4$ & & 1 & $1+2$ & $1+2+3$ & & $1+2+3+4$ & \\
\hline (1) Geography & $-0.239 *$ & $-0.162 * *$ & $-0.283 * *$ & -0.163 & & $-0.152 *$ & $-0.084 * *$ & -0.052 & $* *$ & 0.031 & \\
\hline (2) Location & & -0.181 & 0.024 & 0.05 & & & -0.123 & 0.021 & & 0.039 & \\
\hline (3) Geo * location & & $0.093 *$ & $0.137 *$ & 0.081 & $* *$ & & $0.008 *$ & 0.012 & $* * *$ & 0.007 & $* *$ \\
\hline (4) Infrastructure & & & $-0.118 *$ & -0.024 & $* *$ & & & -0.237 & $*$ & -0.064 & ** \\
\hline (6) Private assets & & & & -0.185 & $*$ & & & & & -0.258 & $*$ \\
\hline Explained & -0.239 & -0.250 & -0.240 & .0 .241 & & -0.152 & -0.199 & -0.256 & & -0.244 & \\
\hline Residual & 0.022 & 0.033 & 0.023 & 0.003 & & -0.015 & 0.032 & 0.089 & & 0.072 & \\
\hline Total & -0.217 & -0.217 & -0.217 & -0.217 & & -0.167 & -0.167 & -0.167 & & -0.167 & \\
\hline
\end{tabular}

Note: Parameters are significant at the $*=0.01$ level, $* *$ at the 0.5 lvel and $* * *$ at the 0.1 level.

Source: Author's calculation based on 1994 LSMS.

\section{Measuring the Relationship between Assets and Povert y}

\subsection{Conceptual Framework}

Depending on the conceptual framework, the relationship between possession of or access to certain assets and the condition of poverty can be viewed either as a profile of poverty or an attempt to understand its determinants. Based on a static optimization model of household production and consumption, it is possible to derive a relationship between household spending and asset levels which is open to empirical evaluation.

In fact, assuming that households as producers maximize benefits subject to the usual technological restrictions (i.e. production function) and as consumers maximize their welfare by optimizing consumption and work decisions given the level of utility obtained, it is possible to establish a direct connection between possession and access to assets and household spending levels.

Following Sadoulet and de Janvry (1995) and Singhet al. (1986), we assume that the household behaves as if production and consumption/work decisions are made sequentially and therefore we can solve the optimization problem recursively in two steps. In the first step the production problem is solved and in the second step the consumption problem is solved. Therefore the problem of optimization of the household as a producer will be:

$$
\begin{aligned}
\operatorname{Max}\left(q_{a}, x, l\right) \pi= & p_{a} q_{a}-p_{x} x-w l \\
& \text { s.t.:g( } \left.q_{a}, x, l, A q\right)=0,
\end{aligned}
$$


where $q_{a}$ is the quantity produced at a price $p_{a}, x$ are the variable factors used in the production process and $l$ is the amount of hours of work used with a price $w$. $g(0)$ represents the production function and the assets that affect the production decision (e.g. fix capital, and size of the plot) are captured in $A^{q}$.

The reduced form of the model is therefore,

Supply function $\quad q_{a}=q_{a}\left(p_{a}, p_{x}, w ; A^{q}\right)$

Factor demands: $\quad x=x\left(p_{a}, p_{x}, w ; A q\right)$

$$
l=l\left(p_{a}, p_{x}, w ; A q\right)
$$

(3) Maximum profit: $\quad \pi^{*}=\pi^{*}\left(p_{a}, p_{x}, w ; A^{q}\right)$

In the second stage the consumption/work problem is solved, given the level of profit $\pi^{*}$ achieved in production:

$$
\begin{aligned}
& \operatorname{Max}_{(c, c l)} u\left(c, c_{l}: A^{h}\right) \\
& \text { s.t.: } p_{c} c+w c_{l}=\pi *+w E \\
& c_{l}+l^{s}=E
\end{aligned}
$$

where $c$ the set of goods consumed by the household at prices $p_{c}, c_{l}$ and $l^{s}$ are the time the household assigns to work in the house and hours of work out of the household respectively with a total time constraint of E. Finally, Ah are assets that affect the consumption decision.

The reduced form of the sequential model can then be expressed in terms of the demand function for goods:

$$
c=c\left(p_{a}, p_{m}, w, y^{*} ; A_{h}\right)
$$

where $y^{*}=p_{a} q_{a}-p_{x} x-w l+w E$. From this demand functions we can then obtain an expenditure function for the household:

$$
G=c \bullet p_{c}=G(p ; A),
$$

where $p$ is the price vectors and $A$ is the vector of possession of assets that include all the assets the household can access. Even more, these assets can be subdivided according to the degree of transferability into private assets ( $A_{\text {priv }}$ ), public assets $\left(A_{p u b}\right)$ and organizational assets ( $\left.A_{\text {org }}\right)$.

Therefore our equation of expenditures can be expressed as:

$$
G=G\left(p ; A_{\text {priv }}, A_{\text {pub }}, A_{\text {org }}\right)
$$


We run a set of models including separately each of the following groups of explanatory variables: neighboring public assets, private assets and individual characteristics. We then identify the direct externality effects from the presence of each. ${ }^{5}$

We model at least three types of public goods and services: a) "traditional infrastructure" such as transportation, sewer systems, water, electricity which does not generate positive network externalities; b) "human-capital-generating public services" that are capable of creating mobile private assets, such as schooling and health services and c) "information and communication technologies", such as telephone or Internet, all of which generate network externalities For example, an information highway is intrinsically different from a transportation highway.

In order to test whether such non-linearities exist we will include in equation (7) the quadratic terms of the stock of those assets in the specific districts of the household. If the coefficient of the stock of this asset is negative and the coefficient of its squared term positive, then we will have evidence in support of a "critical mass" theory, in which the impact might be insignificant in low intensities of such asset.

Assuming, for example, a quadratic function on the assets, the effect of an increase in one of them on household expenditure can be expressed as:

$$
\begin{aligned}
\frac{\partial G}{\partial A_{i}}= & \sum_{j \in \text { Priv }} \theta_{j} A_{j}+\sum_{j \in \text { Priv }} 2 \eta_{j} A_{j} \sum_{k \in \text { Pub }} \varphi_{k} A_{k} \\
& +\sum_{k \in \text { Pub }} 2 \phi_{k} A_{k}+\sum_{s \in O \operatorname{Org}} \zeta_{s} A_{s}+\sum_{s \in \text { Org }} 2 \zeta A_{s}
\end{aligned}
$$

Which implies that the asset elasticity will be equal to:

$$
\varepsilon_{A j}=\frac{\partial G}{\partial A_{i}} \cdot \frac{A_{j}}{G}
$$

and the cross elasticity will be:

$$
\varepsilon_{A_{i} A_{j}}=\frac{\partial\left(\frac{\partial G}{\partial A_{i}}\right)}{\partial A_{j}} \cdot \frac{A_{j}}{\frac{\partial G}{\partial A_{i}}}
$$

\footnotetext{
${ }^{5}$ Escobal and Torero (2000) additionally test the hypothesis of the presence of spatial concentration, they analyze the importance of neighboring effects by measuring the significance of spatial autocorrelation in each of our specifications and test how it decreases as we include additional groups of regressors. They model spatial dependence as a nuisance (a nuisance since it only pertains to the errors). Formally, this dependence is expressed by means of a spatial process for the error terms, either of an autoregressive or a moving average form (see Anselin, 1980; Anselin, 1990, and Anselin, et al., 1996).
} 
Therefore, we can estimate the own and complementary elasticities -given controls for all other public and private assets will be included-effects of the different types of assets. The analysis of these elasticities as well as some simulations that are carried on should shed light into the complementary nature of public investments and their pattern across the income (expenditure) distribution should make evident the presence of important non-linearities in public investments.

\subsection{Some Preliminary Empirical Results}

Tables 5 and 6 show the results of our reduced form depicted in equation (7). In Table 5 the model is included without interaction terms, while in table 6 the full model including interaction between assets is presented. In both case two estimations are shown. The first column shows the econometric estimation without incorporating the sampling framework (sampling weights, stratification and clustering), while the second column includes the full sampling frame. ${ }^{6}$ All of these estimations are done using the rural households surveyed the Peruvian LSMS of 2000. ${ }^{7}$ As mentioned by Deaton (1997), if the cluster design of the data is ignored, standard formulas for variances of are erroneous generating upward biased estimations, a result which applies essentially in the same way to the formulas for the variance-covariance matrices of regression parameters estimated by OLS. Therefore to solve this problem we use the procedure developed by STATA for correcting the estimated standard errors.

Our results, once we correct for the sampling framework, show that access to human capital assets are critical when explaining the level of per capita expenditure. Education for example shows a significant and positive effect both for the household head and for other adults that are part of the household. ${ }^{8}$ Similarly,

\footnotetext{
${ }^{6}$ With respect to the use of sampling weights there is a important controversy both at the theoretical and practical level. The discussion basically consists in two issues: (i) include or not the sampling weights and the sample design in the estimation of the coefficients ii) to correct or not to correct the standard errors associated to those coefficients (Deaton, 1997; Pfeffermann,1993). A weighted regression provides a consistent estimate of the population regression function, provided of course the assumption about functional form is correct. This is especially relevant in our case in which we are looking at the mean of one variable conditional on others.

${ }^{7}$ In surveys of rural areas such as the LSMS, clusters are often villages, so the households in a single cluster live near one another, and are interviewed at much the same time during the period that the survey team is in the village. As a result, the observations from the same cluster are much more like one another than are observations from different clusters. At the simplest they may be neighborhood effects, so that local eccentriticities are copied by those who live near one another and become more or less uniform within a village (Deaton, 1997).

${ }^{8}$ Even more, when including the square term the sign is also positive and significant for both the household head and the other adult household members which may imply that the return to education increases as the number of years of education increase. However we excluded the square terms from the regression because there were highly collinear with the interactions.
} 
the effect of the migratory experience of the household is positive and significant. Both of these variables are important in rural areas because they can be understood as mobile assets. The analysis also confirms that access to credit and ownership of assets that can be used as collateral has a positive effect on spending and therefore on the probability of not being poor.

In addition, reductions in family size have a significant positive impact on the return on the above-mentioned assets. The concept that an increase in family size implies an increase in the productive resources of the family and therefore an increase in family well-being is not empirically sustained. This could justify public intervention in the area of family planning, but since the variable is endogenous to other decisions and restrictions that affect the household, it is not possible to validate such a policy recommendation without first understanding the mechanism of the determination of family size. As specified in these calculations the variable could in fact be capturing the effect of human capital-related variables that are not easily observable.

When analysing the traditional infrastructure, as expected we find a significant and positive impact over expenditure per capita of access to electricity and access to infrastructure for drinkable water. ${ }^{9}$ In the specific case of time to paved roads and access to primary or secondary schools both of these variables become significant and with the expected signs when taking in to account their complementarities with other assets. Specifically in the case of roads and as mentioned previously an improvement in the transport system could significantly reduce what is a significant constraint on agricultural efforts in the rural areas. The lack of a reliable transportation, reflected in high transport and transaction costs, hampers the capacity of rural households to articulate with markets and forces them to continue in subsistence agriculture. Proximity to markets reduces effective prices of agriculture inputs and outputs. Purchases of modern inputs and sales of outputs decline with distance from market, and transport costs influence farm profits through input use and crop marketing decisions. Even more, we find that there is a strong complementarity between a closer access to roads and telephones, something consistent with the idea of a reduction of transaction costs and an increase to proximity of markets.

Several studies mentioned that telecommunications infrastructure investment lead to economic growth in several ways. Basically, as the access to telephone improves the costs of doing business fall, and output of households should increase (Hardy, 1980; Saunders, etal., 1983). Even more, and as previously mentioned, telephones as an IT technology are intrinsically different from other types of infrastructure: information highways are different from transportation highways. The main characteristic which makes this technology different and

\footnotetext{
${ }^{9}$ In this specific case the variable which is positive and significant at $5 \%$ level of confidence is the number of households with infrastructure for drinkable water. Additionally, these variables could be measuring the need to have a critical mass of households connected to the drinkable water system to be able to cover the significant fix cost needed to incur.
} 
which is not present in other types of infrastructure is network externalities: the more users the more value is derived by those users. Given that these network externalities are not present in the other types of infrastructure one may expect that the returns of this asset will be higher. As expected our results show that access to public telephones ${ }^{10}$ had a significant and positive effect but when interacted with education and time to paved roads, showing not only its importance by itself but also its complementarities with assets of the other two types previously described.

\footnotetext{
${ }^{10}$ Is important to mention that fix telephones are not relevant in rural areas in Peru because of the extreme adverse geography which makes extremely costly the installation of fix phones, therefore access to public phones is the relevant IT variable for these areas.
} 
TABLE 5

REGRESSION ANALYSIS OF THE PER CAPITA EXPENDITURE IN THE HOUSEHOLD

\begin{tabular}{|c|c|c|c|c|}
\hline \multirow[b]{2}{*}{ Family size } & \multicolumn{2}{|l|}{ (1) } & \multicolumn{2}{|l|}{ (2) } \\
\hline & $\begin{array}{r}-0.1510 \\
(23.956)\end{array}$ & $* *$ & $\begin{array}{c}-0.1498 \\
(16.103)\end{array}$ & $* *$ \\
\hline Age & 0.0041 & & 0.0038 & \\
\hline & $(4.065)$ & $* *$ & (3.238) & $* *$ \\
\hline Average education of the household head & $\begin{array}{l}0.0193 \\
(4.424)\end{array}$ & $* *$ & $\begin{array}{c}0.0153 \\
(3.131)\end{array}$ & $* *$ \\
\hline Gender & $\begin{array}{r}-0.0150 \\
(0.334)\end{array}$ & & $\begin{array}{r}-0.0609 \\
(1.106)\end{array}$ & \\
\hline Average education attained by family & $\begin{array}{l}0.0165 \\
(3.901)\end{array}$ & $* *$ & $\begin{array}{r}0.0146 \\
(3.237)\end{array}$ & $* *$ \\
\hline Number of migrants & $\begin{array}{l}0.0408 \\
(3.211)\end{array}$ & $* *$ & $\begin{array}{c}0.0401 \\
(2.223)\end{array}$ & $*$ \\
\hline Possession of financial savings & $\begin{array}{l}0.1272 \\
(1.915)\end{array}$ & & $\begin{array}{r}0.1769 \\
(2.706)\end{array}$ & $* *$ \\
\hline Sewerage & $\begin{array}{l}0.0987 \\
(2.111)\end{array}$ & $*$ & $\begin{array}{l}0.0744 \\
(1.239)\end{array}$ & \\
\hline Electricity & $\begin{array}{l}0.0427 \\
(1.355)\end{array}$ & & $\begin{array}{c}0.0431 \\
(0.894)\end{array}$ & \\
\hline Access to public phones & $\begin{array}{l}0.1371 \\
(3.328)\end{array}$ & $* *$ & $\begin{array}{r}0.1519 \\
(1.771)\end{array}$ & $*$ \\
\hline Access to health services & $\begin{array}{r}-0.0576 \\
(1.759)\end{array}$ & & $\begin{array}{c}-0.0426 \\
(0.763)\end{array}$ & \\
\hline Access to education services & $\begin{array}{r}-0.0361 \\
(1.014)\end{array}$ & & $\begin{array}{c}-0.0055 \\
(0.093)\end{array}$ & \\
\hline Communal association & $\begin{array}{r}-0.0442 \\
(1.481)\end{array}$ & & $\begin{array}{r}-0.0863 \\
(1.751)\end{array}$ & $*$ \\
\hline Leadership in communal association & $\begin{array}{l}0.1365 \\
(2.951)\end{array}$ & ** & $\begin{array}{c}0.1282 \\
(2.854)\end{array}$ & $* *$ \\
\hline Value of durable goods & $\begin{array}{l}0.0000 \\
(5.174)\end{array}$ & $* *$ & $\begin{array}{r}0.0000 \\
(4.946)\end{array}$ & $* *$ \\
\hline Value of agricultural equipment & $\begin{array}{l}0.0000 \\
(1.766)\end{array}$ & & $\begin{array}{r}0.0000 \\
(2.834)\end{array}$ & $* *$ \\
\hline Value of land & $\begin{array}{l}0.0000 \\
(1.000)\end{array}$ & & $\begin{array}{r}0.0000 \\
(0.174)\end{array}$ & \\
\hline Price of livestock & $\begin{array}{l}0.0000 \\
(2.109)\end{array}$ & $*$ & $\begin{array}{r}0.0000 \\
(1.747)\end{array}$ & $*$ \\
\hline Distance to roads & $\begin{array}{r}-0.0094 \\
(3.811)\end{array}$ & $* *$ & $\begin{array}{l}-0.0085 \\
(2.061)\end{array}$ & $*$ \\
\hline Roofs made of tiles or rush mat with mud & $\begin{array}{l}0.0539 \\
(1.816)\end{array}$ & & $\begin{array}{l}0.0759 \\
(1.887)\end{array}$ & $*$ \\
\hline Roofs made of hay or palm leaves & $\begin{array}{r}-0.0868 \\
(1.930)\end{array}$ & & $\begin{array}{r}-0.0938 \\
(1.795)\end{array}$ & $*$ \\
\hline Wooden floors & $\begin{array}{l}0.2372 \\
(4.412)\end{array}$ & $* *$ & $\begin{array}{r}0.2976 \\
(4.118)\end{array}$ & $* *$ \\
\hline Parquet, vinyl or concrete floors & $\begin{array}{c}0.1923 \\
(5.524)\end{array}$ & ** & $\begin{array}{c}0.2313 \\
(4.624)\end{array}$ & $* *$ \\
\hline Percentage of homes with drinkable water in the community & $\begin{array}{l}0.0013 \\
(3.375)\end{array}$ & ** & $\begin{array}{c}0.0018 \\
(3.378)\end{array}$ & ** \\
\hline Constant & $\begin{array}{r}7.4045 \\
(86.011)\end{array}$ & $* *$ & $\begin{array}{r}7.4382 \\
(68.407)\end{array}$ & $* *$ \\
\hline $\begin{array}{l}\text { Observations } \\
\text { R-squared } \\
\text { F.statistic }\end{array}$ & $\begin{array}{c}1174 \\
0.467 \\
41.94 \\
\mathrm{~F}(24.11\end{array}$ & & $\begin{array}{c}1174 \\
21.65 \\
F(24.80)\end{array}$ & \\
\hline
\end{tabular}

Absolute value of t-statistic in parentheses. The Cook Weisber test for heteroskedasticity was carried and the null hypothesis of constant variance could not be rejected. * significant at $5 \%$ level. ** significant at $1 \%$ level.

(1) Simple regression analysis

(2) Regression analysis with sampling frame. 
TABLE 6

REGRESSION ANALYSIS OF THE PER CAPITA EXPENDITURE IN THE HOUSEHOLD USING VARIABLES INTERACTIONS

\begin{tabular}{|c|c|c|c|c|}
\hline & (1) & & (2) & \\
\hline \multirow[t]{2}{*}{ Family size } & -0.1499 & & -0.1490 & \\
\hline & $(24.008)$ & $* *$ & $(16.560)$ & $* *$ \\
\hline \multirow[t]{2}{*}{ Age } & 0.0038 & & 0.0034 & \\
\hline & $(3.749)$ & $* *$ & 0.0000 & \\
\hline \multirow[t]{2}{*}{ Average education of the household head } & 0.0175 & & 0.0130 & \\
\hline & $(3.816)$ & $* *$ & $(2.582)$ & $* *$ \\
\hline \multirow[t]{2}{*}{ Gender } & -0.0172 & & -0.0630 & \\
\hline & $(0.389)$ & & $(1.171)$ & \\
\hline \multirow[t]{2}{*}{ Average education attained by family } & 0.0153 & & 0.0138 & \\
\hline & $(3.641)$ & $* *$ & $(3.004)$ & $* *$ \\
\hline \multirow[t]{2}{*}{ Number of migrants } & 0.0425 & & 0.0452 & \\
\hline & $(3.372)$ & $* *$ & $(2.670)$ & ** \\
\hline \multirow[t]{2}{*}{ Possession of financial savings } & 0.1291 & & 0.1743 & \\
\hline & $(1.959)$ & & $(2.529)$ & $* *$ \\
\hline \multirow[t]{2}{*}{ Sewerage } & 0.0386 & & -0.0166 & \\
\hline & $(0.702)$ & & $(0.271)$ & \\
\hline \multirow[t]{2}{*}{ Electricity } & 0.0838 & & 0.0850 & \\
\hline & $(1.071)$ & & $(0.974)$ & \\
\hline \multirow[t]{2}{*}{ Access to public phones } & 0.0831 & & 0.0272 & \\
\hline & $(1.070)$ & & $(0.284)$ & \\
\hline \multirow[t]{2}{*}{ Access to health services } & -0.0504 & & -0.0373 & \\
\hline & $(1.544)$ & & $(0.715)$ & \\
\hline \multirow[t]{2}{*}{ Access to education services } & -0.0874 & & -0.0629 & \\
\hline & $(1.966)$ & $*$ & $(1.147)$ & \\
\hline \multirow[t]{2}{*}{ Communal association } & 0.0164 & & -0.0157 & \\
\hline & $(0.474)$ & & $(0.263)$ & \\
\hline \multirow[t]{2}{*}{ Leadership in communal association } & 0.1401 & & 0.1300 & \\
\hline & $(3.063)$ & $* *$ & (2.993) & $* *$ \\
\hline \multirow[t]{2}{*}{ Value of durable goods } & 0.0000 & & 0.0000 & \\
\hline & $(5.605)$ & $* *$ & $(5.155)$ & $* *$ \\
\hline \multirow[t]{2}{*}{ Value of agricultural equipment } & 0.0000 & & 0.0000 & \\
\hline & $(0.183)$ & & $(0.548)$ & \\
\hline \multirow[t]{2}{*}{ Value of land } & 0.0000 & & 0.0000 & \\
\hline & $(1.774)$ & & $(2.372)$ & $* *$ \\
\hline \multirow[t]{2}{*}{ Price of livestock } & 0.0000 & & $(2.960)$ & $* *$ \\
\hline & $(1.730)$ & & $(1.525)$ & \\
\hline \multirow[t]{2}{*}{ Distance to roads } & 0.0014 & & 0.0082 & \\
\hline & $(0.321)$ & & $(1.359)$ & \\
\hline Roofs made of tiles or rush mat with mud & 0.0840 & & 0.1142 & \\
\hline & $(2.506)$ & $*$ & $(2.713)$ & ** \\
\hline Roofs made of hay or palm leaves & -0.1000 & & -0.1018 & \\
\hline & $(2.232)$ & * & $(2.060)$ & $*$ \\
\hline Wooden floors & 0.2275 & & 0.2734 & \\
\hline & $(4.280)$ & $* *$ & (3.934) & ** \\
\hline Parquet, vinyl or concrete floors & 0.1851 & & 0.2159 & \\
\hline & $(5.317)$ & $* *$ & $(4.549)$ & $* *$ \\
\hline Percentage of homes with drinkable water in the community & 0.0011 & & 0.0016 & \\
\hline & $(2.837)$ & $* *$ & (2.956) & $* *$ \\
\hline Squared value of land & 0.0000 & & 0.0000 & \\
\hline & $(2.399)$ & * & (3.174) & $* *$ \\
\hline Sewerage and access to public phones & 0.1775 & & 0.2945 & \\
\hline & $(1.860)$ & & $(2.835)$ & $* *$ \\
\hline Electricity and communal association & $(1.860)$ & & $(2.835)$ & $* *$ \\
\hline & -0.2052 & & -0.1799 & \\
\hline & $(3.384)$ & $* *$ & (2.315) & $*$ \\
\hline
\end{tabular}


TABLE 6

(Continuation)

\begin{tabular}{|c|c|c|c|c|}
\hline & (1) & & (2) & \\
\hline Access to public phones and distance to roads & $\begin{array}{r}-0.0155 \\
(2.953)\end{array}$ & $* *$ & $\begin{array}{r}-0.0245 \\
(3.937)\end{array}$ & $* *$ \\
\hline Value of agricultural equipment $\mathrm{x}$ price of livestock & $\begin{array}{c}0.0000 \\
(1.783)\end{array}$ & & $\begin{array}{r}0.0000 \\
(2.388)\end{array}$ & $* *$ \\
\hline Average education of the household head $\mathrm{x}$ access to public phones & $\begin{array}{l}0.0072 \\
(0.802)\end{array}$ & & $\begin{array}{r}0.0139 \\
(1.973)\end{array}$ & $*$ \\
\hline Access to education services $\mathrm{x}$ electricity & $\begin{array}{l}0.1486 \\
(2.155)\end{array}$ & * & $\begin{array}{r}0.1347 \\
(1.676)\end{array}$ & $*$ \\
\hline Distance to roads $\mathrm{x}$ roofs made of tiles or rush mat with mud & $\begin{array}{r}-0.0198 \\
(1.901)\end{array}$ & & $\begin{array}{l}-0.0231 \\
(1.800)\end{array}$ & $*$ \\
\hline Constant & $\begin{array}{r}7.4454 \\
(83.291)\end{array}$ & $* *$ & $\begin{array}{r}7.4828 \\
(70.692)\end{array}$ & ** \\
\hline $\begin{array}{l}\text { Observations } \\
\text { R-squared } \\
\text { F.statistic }\end{array}$ & $\begin{array}{c}1174 \\
0.485 \\
33.65 \\
\mathrm{~F}(32,1141)\end{array}$ & & $\mathrm{F}(31,73)$ & \\
\hline
\end{tabular}

Absolute value of t-statistic in parentheses. The Cook Weisber test for heteroskedasticity was carried and the null hypothesis of constant variance could not be rejected.

$*$ significant at $5 \%$ level. ** significant at $1 \%$ level.

(1) Simple regression analysis

(2) Regression analysis with sampling frame.

Among the additional most important interactions that are shown to be significant we should mention some obvious like the complementarity's between access to road infrastructure and the fact that the house has better roofs which could be a result of a major market value of the house once there is a close by paved road. At the same time several interaction point to complementarity's nature on public and private assets, for example between access to education infrastructure and access to electricity. Finally, statistical evidence was found that variables of public and organizational capital such as being director of the local organizations have a similar positive impact.

In the next section, using the parameters estimated from the spending equations, we calculated the impact of changes in the ownership and access to complementary assets on the level of expenditure.

4.3. Simulating the Impact of Access to different Types of Asset: Assessing Complementarities

Using the expenditure function estimated in the previous section we have run some simulations to show not only the importance of key assets in explaining per-capita expenditure, but also the importance of complementarities in the allocation of public infrastructure.

Table 7 shows how much will per capita expenditure increase if we provide some additional infrastructure to rural dwellers. Here we evaluate the impact of 
public phones, education, sewerage systems and road infrastructure in each of the 5 quintiles of the rural expenditure distribution. For example Access to public phones will increase per-capita expenditure by less than $2 \%$ in the poorest quintile of the distribution and will increase it by $12 \%$ for the richest quintile of the distribution. A similar pattern can be observed with respect to access to other key assets that we evaluate here.

TABLE 7

VARIATION IN HOUSEHOLD EXPENDITURE THROUGH ACCESS TO SELECTED ASSETS

(By quintiles - percentage)

\begin{tabular}{lccccc}
\hline & 1 & 2 & 3 & 4 & 5 \\
\hline & 1.72 & 3.75 & 5.45 & 6.10 & 12.04 \\
Access to public phones & 3.27 & 3.45 & 4.47 & 5.87 & 6.97 \\
Access to primary and secondary schools & 3.41 & 3.53 & 4.11 & 4.07 & 7.57 \\
Access to sewerage & 0.95 & 1.04 & 1.30 & 1.17 & 1.52 \\
Access to main road (reduction in 1 hour) & 1.90 & 2.09 & 2.61 & 2.36 & 3.06 \\
Access to main road (reduction in 2 Hours) & & & & & \\
\hline
\end{tabular}

Table 8 shows the results of these simulations contrasting the effects of provision of public infrastructure between poor and non-poor rural dwellers. As expected although all rural inhabitants benefit with the provision of additional public infrastructure, non-poor rural dweller tend to benefit more. This is obviously the effect of the additional private (and public) asset endowment that non-poor have in comparison with the rural poor. A better educated rural dweller typically positioned in the richest quintile may use the same public infrastructure in more profitable way than a less educated rural dweller positioned in the poorest quintile.

TABLE 8

VARIATION IN HOUSEHOLD EXPENDITURE THROUGH ACCESS TO SELECTED ASSETS

(Percentage)

\begin{tabular}{lcc}
\hline & No poor & Poor \\
\hline Access to public phones & 8.26 & 3.87 \\
Access to primary and secondary schools & 6.24 & 3.75 \\
Access to sewerage & 6.04 & 3.43 \\
Access to main road (reduction in 1 hour) & 1.37 & 1.06 \\
Access to main road (reduction in 2 hours) & 2.76 & 2.14 \\
\hline
\end{tabular}


TABLE 9

VARIATION IN HOUSEHOLD EXPENDITURE THROUGH SIMULTANEOUS ACCESS TO SELECTED ASSETS

(By quintiles - percentage)

Access to public phones

Access to primary and secondary schools

Access to sewerage

Access to main road (reduction in 1 hour)

Access to main road (reduction in 2 hours)

\begin{tabular}{crrrrr}
\hline & 1 & 2 & 3 & 4 & \multicolumn{1}{c}{5} \\
\hline $1+2$ & 5.06 & 7.34 & 10.17 & 12.33 & 19.85 \\
$1+3$ & 33.44 & 36.05 & 37.70 & 39.18 & 42.49 \\
$1+4$ & 4.25 & 6.33 & 8.07 & 8.74 & 14.82 \\
$1+5$ & 6.84 & 8.97 & 10.75 & 11.43 & 17.67 \\
$2+3$ & 6.79 & 7.10 & 8.77 & 10.18 & 15.06 \\
$2+4$ & 4.25 & 4.53 & 5.83 & 7.11 & 8.59 \\
$2+5$ & 5.24 & 5.62 & 7.20 & 8.37 & 10.24 \\
$3+4$ & 0.95 & 1.04 & 1.30 & 1.17 & 1.52 \\
$3+5$ & 1.90 & 2.09 & 2.61 & 2.36 & 3.06 \\
$1+2+3$ & 37.81 & 40.75 & 43.86 & 47.35 & 52.42 \\
$1+2+4$ & 8.38 & 10.83 & 13.99 & 16.08 & 23.93 \\
$1+2+5$ & 11.81 & 14.43 & 17.93 & 19.96 & 28.16 \\
$1+3+4$ & 37.66 & 40.47 & 42.47 & 43.82 & 47.35 \\
$1+3+5$ & 42.02 & 45.04 & 47.40 & 48.63 & 52.38 \\
$2+3+4$ & 7.80 & 8.22 & 10.17 & 11.47 & 16.81 \\
$2+3+5$ & 8.82 & 9.34 & 11.60 & 12.77 & 18.59 \\
$1+2+3+4$ & 41.17 & 45.32 & 48.84 & 52.27 & 57.62 \\
$1+2+3+5$ & 46.67 & 50.05 & 53.99 & 57.35 & 62.99 \\
\hline
\end{tabular}

Table 9 and 10 shows the combined effect of delivering different combinations of public infrastructure to the rural inhabitants in Peru. Two very interesting conclusions emerge from analyzing these simulations. First the results show a positive effect of being able to access to more than one asset at the same time. The combination of one or more assets sometimes increase the impact over the welfare of the households in more than the sum of its individual impacts, and in some cases the effect is multiplicative. Second, complementarity investments tend to close the gap between poor and non poor rural dwellers. For example while investing in public phones increases per capita expenditures in the richest and poorest quintile in $12 \%$ and less than $2 \%$, respectively, adding an additional investment, like improved roads increases per capita expenditures in the richest and poorest quintile in $18 \%$ and about $7 \%$, respectively. Adding a third asset, like sewerage, increases per capita expenditures in the richest and poorest quintile in $52 \%$ and $42 \%$, respectively. The driving force behind these results is that those lacking these additional assets are increasing in the poorest segments so their marginal rate of return is higher. This is consistent with the idea that the simultaneous provision of public assets is an effective way of equalizing opportunities between the poor and non poor. 
TABLE 10

VARIATION IN HOUSEHOLD EXPENDITURE THROUGH ACCESS TO SELECTED ASSETS

(Percentage)

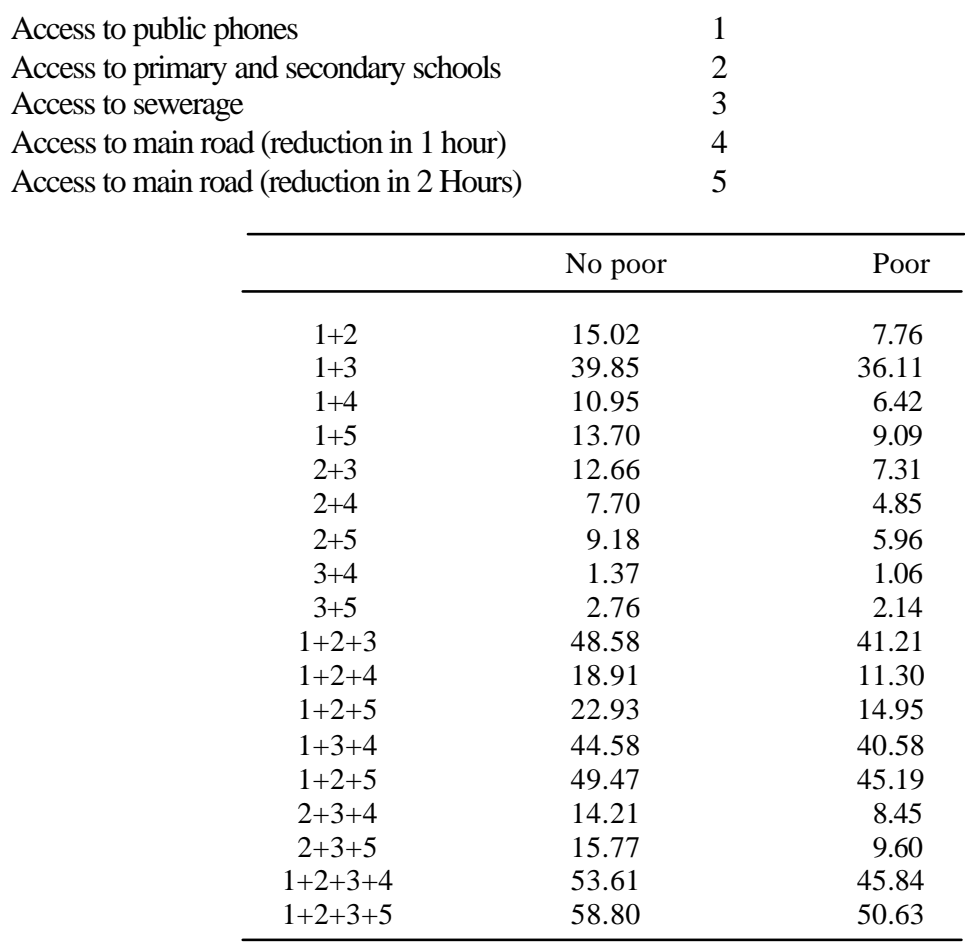

\section{Conclusions}

This study has attempted to better understand the connection between assets and poverty. We also evaluate the fact that geographic externalities arising from natural geographic characteristics, like the adverse ones present in Peru, could be the main reason explaining why poor households cannot escape out of poverty. Our results show that what seem to be sizable geographic differences in living standards in Peru can be almost fully explained when one takes into account the spatial concentration of households with readily observable non-geographic characteristics, in particular public and private assets.

Our analysis concentrates in studying the impact on poverty of having access to public and private assets. We study three types of public goods and services: traditional infrastructure, human-capital-generating public services and information and communication technologies with their additional characteristic 
of network externality. The study shows the differential impact on poverty of each of these types of investments, as well as the interaction effect between so- called traditional types of infrastructure and those, which generate network externalities.

Within the human capital generating public services education (both attainment and access to primary and secondary schools in the village), family size, and social capital are of significant importance in explaining the state of poverty of individuals. The analysis also confirms that ownership of assets that can be used as collateral has a positive effect on spending and on the probability of not being poor

On the other hand, statistical evidence was found that access to traditional infrastructure such as water; sewerage, electricity and paved roads have a similar impact as the human capital generating public services. In this respect, the empirical analysis is consistent with the view that the behind the unequal access to assets underlies the problem of high poverty rates and unequal income distribution that Peru faces. Finally, access to telephones, the main information and communication technology available in rural Peru also had a significant positive effect on the welfare of rural households.

When looking to asset complementarities the results show a positive effect on per-capita expenditure and poverty of being able to access to more than one asset at the same time. In this sense access or ownership of a combination of two or more assets tends to have a higher welfare impact than the sum of the individual impacts. For example, if a poor household has access solely to telephone its expenditure will increase in $4 \%$. If it has improved access to a road (reduction in one hour of travel time to the market) its expenditure increases in $1 \%$ However, if access to both assets is granted its expenditure increases in 7\%. Even more, if in addition this household has access to primary and secondary schools in its village then its expenditure will increase in more than $11 \%$, while the arithmetic sum of the increase in expenditure of having each asset alone will be only 7\%. This result clearly shows the role of public policy in terms of provision of services and infrastructure as a mechanism to strengthen the return from private assets and thus facilitates reduction of poverty. The results also show that the additional provision of public goods serves as a equalizing force between the rural poor and the non poor. 


\section{REFERENCES}

Anselin, L. (1990), Estimation Methods for Spatial Autoregressive Structures. Regional Science Dissertation and Monograph Series Nr. 8, Cornell University, Ithaca, New York.

Anselin, L. (1988), Spatial Econometrics: Methods and Models, Kluwer Academic Publishers, The Netherlands.

Anselin, L.; A. Varga and A. Zoltan (1996), Local Geographic Spillovers Between University Research and High Technology Innovations: A Spatial Econometric Approach. Research Paper No. 9606, Regional Institute and Department of Economics, West Virginia University, Morgantown.

Bebbington, A. (1999), "Capitals and Capabilities: A Framework for Analyzing Peasant Viability, Rural Livelihoods and Poverty." World Development 27(12): 2021-44.

Birdsall, N. and J. L. Londoño (1998), “Assets Inequality Matters,” American Economic Review, Papers and Proceedings, May.

Deaton, A. (1997), The Analysis of Household Surveys. A Microeconometric Approach to Development Policy. World Bank, The Johns Hopkins University Press, Washington D.C.

Engerman, S. L. and K. L. Sokoloff, (1998), "Factor Endowments, Institutions, and Differential Paths of Growth among New World Economies: A View from Economic Historians of the United States?" In: Stephen Haber (ed.) How Latin American Fell Behind: Essays on the Economic Histories of Brazil and Mexico, 1800-1914. Stanford, CA: Stanford University Press.

Escobal, J.; J. Saavedra and M. Torero (1998), Los Activos de los Pobres en el Perú. Mimeo. Research Report presented to IDB Research Network.

Escobal, J. and M. Torero (2000), Does Geography Explain Differences in Economic Growth in Peru? Research Network Working Paper, IDB. Washington D.C. Submitted to the review of Regional Studies, 50.

Hardy, A. (1980), "The Role of the Telephone in Economic Development". Telecommunications Policy, 8(1): 23-44.

Jalan, J. and M. Ravallion (1998), “Geographic Poverty Traps?” In: Institute for Economic Development Discussion Paper Series, $\mathrm{Nr}$ 86, May.

Pfeffermann, D. (1993). "The Role of Sampling Weights When Modeling Survey Data". International Statistical Review, 61: 317-337.

Ravallion, M. and Q. Wodon (1997), "Poor Areas, Or Only Poor People?" In: Policy Research Working Paper, ${ }_{2}$ r 1798, World Bank, Washington DC.

Saunders, R.; J.J. Warford and B. Wellenius; (1983), "Telecommunications and Economic Development”. Second Edition, World Bank, Johns Hopkins University Press, London.

Sadoulet, E. and A. de Janvry (1995), Quantitative Development Policy Analysis. Baltimore: Johns Hopkins University Press.

Singh, I.; L. Squire and J. Strauss, Eds. (1986), Agricultural Household Models: Extensions, Applications, and Policy. Johns Hopkins University Press for the World Bank, Baltimore and London. 


\section{DATA SOURCES}

At household level

- $\quad$ Living Standard Measurement Surveys 1985-86 and 1994, Cuanto Institute.

At province-level

- $\quad$ Population and Household Censuses 1972, 1981 and 1994, Instituto Nacional de Estadística e Informática: population and household characteristics.

- Third National Agrarian Census 1994, Instituto Nacional de Estadística e Informática: agricultural variables, cattle and land.

- $\quad$ Basic Needs Map 1994. Instituto Nacional de Estadística e Informática: basic needs and health variables

- Social Investment Map 1994, FONCODES: poverty index and its components, living standard.

Geographic variables

- $\quad$ Arc data Online in: http://www.esri.com/data/online/esri/wothphysic.html. This information was afterwards overlaid on a map of Peru at provincial and district levels. The score for each province or district was selected according to the position of its centroid on the thematic map: earthquake zones, precipitation, soils and vegetation.

- Natural Resources in Peru 1995, Instituto Nacional de Recursos Naturales: bioclimate and land potential scores.

- Social Investment Map 1994, FONCODES: altitude and geographic location. 


\section{APPENDIX 1}

TABLE A. 1

BASIC STATISTICS

\begin{tabular}{|c|c|c|c|}
\hline & Mean & $\begin{array}{l}\text { Rural Peru } \\
\text { median }\end{array}$ & $\begin{array}{l}\text { Standard } \\
\text { deviation }\end{array}$ \\
\hline \multicolumn{4}{|l|}{ Personal and family characteristics of the household head } \\
\hline Gender & 0.90 & 1.00 & 0.31 \\
\hline Age & 45.32 & 42.00 & 15.22 \\
\hline Marital status & 0.51 & 1.00 & 0.50 \\
\hline Family size & 5.12 & 5.00 & 2.12 \\
\hline Number of migrants & 0.76 & 0.00 & 1.05 \\
\hline \multicolumn{4}{|l|}{ Human capital assets } \\
\hline Average education attained by family & 5.97 & 6.00 & 3.44 \\
\hline Average education of the household head & 6.07 & 6.00 & 3.79 \\
\hline Access to primary school & 0.81 & 1.00 & 0.39 \\
\hline Access to secondary school & 0.24 & 0.00 & 0.43 \\
\hline Access to health services & 0.29 & 0.00 & 0.45 \\
\hline Communal association & 0.70 & 1.00 & 0.46 \\
\hline Leadership in communal associations & 0.09 & 0.00 & 0.28 \\
\hline \multicolumn{4}{|l|}{ Physical capital assets } \\
\hline Brick and concrete walls & 0.07 & 0.00 & 0.26 \\
\hline Wooden walls & 0.17 & 0.00 & 0.38 \\
\hline Roofs made of tiles or rush mat with mud & 0.34 & 0.00 & 0.48 \\
\hline Roofs made of hay or palm leaves & 0.14 & 0.00 & 0.34 \\
\hline Wooden floors & 0.09 & 0.00 & 0.28 \\
\hline Parquet, vinyl or concrete floors & 0.21 & 0.00 & 0.41 \\
\hline Value of durable goods & $4,279.48$ & $3,841.63$ & $3,576.86$ \\
\hline Value of agricultural equipment & 292.55 & 101.97 & 811.63 \\
\hline Value of land & 3.715 .37 & $2,244.15$ & $4,409.16$ \\
\hline Price of livestock & 1.967 .62 & 492.39 & $4,168.02$ \\
\hline \multicolumn{4}{|l|}{ Financial capital assets } \\
\hline Possession of financial savings & 0.04 & 0.00 & 0.20 \\
\hline \multicolumn{4}{|l|}{ Traditional infrastructure } \\
\hline Drinkable water & 0.35 & 0.00 & 0.48 \\
\hline Sewerage & 0.10 & 0.00 & 0.30 \\
\hline Electricity & 0.34 & 0.00 & 0.48 \\
\hline Distance to roads & 2.45 & 0.60 & 5.50 \\
\hline Percentage of homes with electricity in the community & 34.33 & 0.00 & 42.40 \\
\hline Percentage of homes with drinkable water in the community & 35.26 & 16.67 & 38.56 \\
\hline \multicolumn{4}{|l|}{ Information and communication technologies } \\
\hline Percentage of homes with telephone in the community & 14.82 & 0.00 & 32.30 \\
\hline Access to public phones & 0.15 & 0.00 & 0.36 \\
\hline
\end{tabular}

Note:

Personal and family characteristics of the household head Gender

Age

Marital status

Family size

Number of migrants

( 1 if male, 0 if female)

years

( $1=$ married, 0 single)

number of members

Human capital assets

Average education attained by family

number of members

Average education of the household head

Years of education

Years of education 
Access to primary school

Access to secondary school

Access to health services

Communal association

Leadership in communal associations

Physical capital assets

Brick and concrete walls

Wooden walls

Roofs made of tiles or rush mat with mud

Roofs made of hay or palm leaves

Wooden floors

Parquet, vinyl or concrete floors

Value of durable goods

Value of agricultural equipment

Value of land

Price of livestock

Financial capital assets

Possession of financial savings

Traditional infrastructure

Drinkable water

Sewerage

Electricity

Distance to roads

Percentage of homes with electricity in the community

Percentage of homes with drinkable water in the community

Information and communication technologies

Percentage of homes with telephone in the community

Access to public phones
( $1=$ if primary school in village, 0 if no primary school in village)

( $1=$ if secondary school in village, 0 if no secondary school in village)

( $1=$ if health services in village, 0 if no health service in village)

( $1=$ if participate in communal association, 0

if not participate in communal association)

( $1=$ if leader of communal association, 0 if not leader of communal association)

( $1=$ house has brick and concrete walls, $0=$ if house not has brick and concrete walls)

( $1=$ house has wooden walls, $0=$ if house not has wooden walls)

( $1=$ Roofs made of tiles or rush mat with mud, 0 if roofs are not made of tiles or rich mat with mud)

( $1=$ Roofs made of hay or palm leaves, 0 if roofs are not made of hay or palm leaves)

( $1=$ Wooden floors, $0=$ no wooden floors $)$

$(1=$ Parquet, vinyl or concrete floors, $=$ no parquet, vinyl or concrete floors)

Constant soles at prices of Lima (capital of Peru)

Constant soles at prices of Lima (capital of Peru)

Constant soles at prices of Lima (capital of Peru)

Constant soles at prices of Lima (capital of Peru)

( $1=$ if household have financial savings, 0 if household does not have financial savings)

(1= if Drinkable water at the household, 0 if no drinkable water at the household)

( $1=$ if sewerage connected to the household, 0 if no sewerage connected to the household)

( $1=$ if access to electricity at the household, 0 if no access to electricity at the household) kilometers

percentage

percentage

percentage

$(=1$ if there is a public phone in the village, 0 if there is no public phone in the village) 
TABLE A.2

BASIC STATISTICS BY QUINTILE

\begin{tabular}{|c|c|c|c|c|c|c|c|c|c|c|c|c|c|c|c|}
\hline & \multicolumn{3}{|c|}{ I } & \multicolumn{3}{|c|}{ II } & \multicolumn{3}{|c|}{ III } & \multicolumn{3}{|c|}{ IV } & \multicolumn{3}{|c|}{$\mathrm{V}$} \\
\hline & Mean & Median & St. Dv. & Mean & Median & St. Dv. & Mean & Median & St. Dv. & Mean & Median & St. Dv. & Mean & Median & St. Dv. \\
\hline \multicolumn{16}{|l|}{ Personal and family characteristics of the household head } \\
\hline Gender & 0.91 & 1.00 & 0.28 & 0.89 & 1.00 & 0.31 & 0.91 & 1.00 & 0.29 & 0.89 & 1.00 & 0.31 & 0.87 & 1.00 & 0.34 \\
\hline Age & 44.00 & 42.00 & 12.65 & 42.80 & 40.00 & 14.39 & 44.76 & 42.00 & 15.54 & 45.73 & 44.00 & 15.74 & 49.35 & 47.00 & 16.76 \\
\hline Marital status & 0.54 & 1.00 & 0.50 & 0.47 & 0.00 & 0.50 & 0.56 & 1.00 & 0.50 & 0.50 & 0.00 & 0.50 & 0.46 & 0.00 & 0.50 \\
\hline Family size & 6.77 & 7.00 & 2.05 & 5.50 & 5.00 & 1.97 & 5.23 & 5.00 & 1.74 & 4.55 & 4.00 & 1.76 & 3.52 & 3.00 & 1.61 \\
\hline Number of migrants & 0.76 & 0.00 & 1.21 & 0.78 & 0.00 & 1.05 & 0.71 & 0.00 & 0.99 & 0.84 & 0.00 & 1.06 & 0.68 & 0.00 & 0.94 \\
\hline \multicolumn{16}{|l|}{ Human capital assets } \\
\hline Average education attained by family & 5.09 & 5.25 & 2.50 & 5.65 & 6.00 & 3.09 & 6.15 & 6.00 & 2.94 & 6.07 & 6.00 & 3.67 & 6.91 & 7.00 & 4.45 \\
\hline Average education of the household head & 5.11 & 6.00 & 3.08 & 5.64 & 6.00 & 3.54 & 6.16 & 6.00 & 3.64 & 6.35 & 6.00 & 3.90 & 7.08 & 6.00 & 4.41 \\
\hline Access to secondary school & 0.25 & 0.00 & 0.43 & 0.22 & 0.00 & 0.41 & 0.23 & 0.00 & 0.42 & 0.30 & 0.00 & 0.46 & 0.21 & 0.00 & 0.40 \\
\hline Access to health services & 0.29 & 0.00 & 0.45 & 0.26 & 0.00 & 0.44 & 0.28 & 0.00 & 0.45 & 0.36 & 0.00 & 0.48 & 0.27 & 0.00 & 0.45 \\
\hline Communal association & 0.74 & 1.00 & 0.44 & 0.72 & 1.00 & 0.45 & 0.74 & 1.00 & 0.44 & 0.72 & 1.00 & 0.45 & 0.59 & 1.00 & 0.49 \\
\hline Leadership in communal association & 0.06 & 0.00 & 0.24 & 0.07 & 0.00 & 0.25 & 0.09 & 0.00 & 0.29 & 0.11 & 0.00 & 0.32 & 0.10 & 0.00 & 0.30 \\
\hline \multicolumn{16}{|l|}{ Physical capital assets } \\
\hline Brick and concrete walls & 0.03 & 0.00 & 0.16 & 0.06 & 0.00 & 0.23 & 0.07 & 0.00 & 0.25 & 0.10 & 0.00 & 0.30 & 0.11 & 0.00 & 0.31 \\
\hline Wooden walls & 0.21 & 0.00 & 0.41 & 0.20 & 0.00 & 0.40 & 0.14 & 0.00 & 0.35 & 0.18 & 0.00 & 0.39 & 0.12 & 0.00 & 0.33 \\
\hline Roofs made of tiles or rush mat with mud & 0.28 & 0.00 & 0.45 & 0.30 & 0.00 & 0.46 & 0.40 & 0.00 & 0.49 & 0.33 & 0.00 & 0.47 & 0.41 & 0.00 & 0.49 \\
\hline Roofs made of hay or palm leaves & 0.21 & 0.00 & 0.41 & 0.16 & 0.00 & 0.36 & 0.10 & 0.00 & 0.30 & 0.15 & 0.00 & 0.36 & 0.06 & 0.00 & 0.23 \\
\hline Wooden floors & 0.11 & 0.00 & 0.31 & 0.09 & 0.00 & 0.29 & 0.06 & 0.00 & 0.24 & 0.12 & 0.00 & 0.33 & 0.05 & 0.00 & 0.21 \\
\hline Parquet, vinyl or concrete floors & 0.13 & 0.00 & 0.33 & 0.13 & 0.00 & 0.34 & 0.17 & 0.00 & 0.37 & 0.24 & 0.00 & 0.43 & 0.38 & 0.00 & 0.49 \\
\hline Value of land & $3,576.69$ & $2,423.74$ & $3,490.04$ & $3,204.09$ & $1,994.80$ & $3,268.19$ & $3,636.14$ & $1,994.80$ & $4,570.58$ & $3,945.82$ & $2,244.15$ & $4,744.44$ & 4.216 .23 & $2,423.74$ & $5,543.48$ \\
\hline Price of livestock & $1,747.67$ & 614.98 & $2,389.64$ & $1,612.81$ & 333.13 & $2,916.48$ & $1,940.01$ & 678.79 & $2,919.98$ & $2,435.44$ & 622.38 & $6,522.92$ & $2,102.77$ & 299.22 & $4,633.75$ \\
\hline \multicolumn{16}{|l|}{ Financial capital assets } \\
\hline Possession of financial savings & 0.02 & 0.00 & 0.13 & 0.02 & 0.00 & 0.14 & 0.03 & 0.00 & 0.16 & 0.06 & 0.00 & 0.24 & 0.08 & 0.00 & 0.27 \\
\hline \multicolumn{16}{|l|}{ Traditional infrastructure } \\
\hline Drinkable water & 0.20 & 0.00 & 0.40 & 0.33 & 0.00 & 0.47 & 0.37 & 0.00 & 0.48 & 0.40 & 0.00 & 0.49 & $0^{\prime} .46$ & 0.00 & 0.50 \\
\hline Sewerage & 0.08 & 0.00 & 0.27 & 0.08 & 0.00 & 0.27 & 0.11 & 0.00 & 0.31 & 0.07 & 0.00 & 0.25 & 0.18 & 0.00 & 0.38 \\
\hline Electricity & 0.24 & 0.00 & 0.43 & 0.24 & 0.00 & 0.43 & 0.32 & 0.00 & 0.47 & 0.40 & 0.00 & 0.49 & 0.51 & 1.00 & 0.50 \\
\hline Distance to roads & 3.29 & 1.00 & 6.94 & 2.75 & $1-00$ & 5.90 & 2.57 & 1.00 & 5.47 & 2.10 & 0.40 & 5.27 & 1.54 & 0.30 & 3.02 \\
\hline Percentage of homes with electricity in the community & 23.81 & 0.00 & 37.55 & 26.52 & 0.00 & 38.95 & 35.04 & 0.00 & 43.36 & $38-71$ & 0.00 & 43.52 & 47.61 & 51.52 & 44.19 \\
\hline $\begin{array}{l}\text { Percentage of home with drinkable water in the } \\
\text { community }\end{array}$ & 24.22 & 8.33 & 32.34 & 31.98 & 16.67 & 36.81 & 36.45 & 16.67 & 38.02 & 36.60 & 16.67 & 39.45 & 47.12 & 50.00 & 42.22 \\
\hline \multicolumn{16}{|l|}{ Information and communication technologies } \\
\hline Percentage of homes with telephone in the community & 12.44 & 0.00 & 30.36 & 11.35 & 0.00 & 29.53 & 13.79 & 0.00 & 31.76 & 15.97 & 0.00 & 33.46 & 20.57 & 0.00 & 35.48 \\
\hline Access to public phones & 0.12 & 0.00 & 0.32 & 0.11 & 0.00 & 0.31 & 0.14 & 0.00 & 0.34 & 0.15 & 0.00 & 0.36 & 0.23 & 0.00 & 0.42 \\
\hline
\end{tabular}

